\title{
25 Research Soure \\ The Effects of Taxation on Economic Development: the Moderating Role of Tax Compliance Among SMEs
}

Eugene Adjei Werekoh ( $\square$ eugeneagyei18@gmail.com )

Kwame Nkrumah University of Science and Technology

\section{Research Article}

Keywords: tax compliance, taxation, economic development, SMEs and economy

Posted Date: January 11th, 2022

DOI: https://doi.org/10.21203/rs.3.rs-1238141/v1

License: (c) (i) This work is licensed under a Creative Commons Attribution 4.0 International License.

Read Full License 


\section{Abstract}

The amount of revenue collected often determines a country's economic growth and development. Taxes continue to be one of the most important constituents in managing nationwide income in emerging and developed nations. In this sense, tax evasion might have serious effects, especially because the global cost of non-compliance by taxpayers is quite significant. Small and medium-sized firms (SMEs) are the backbone of economies around the world, driving economic progress and growth, as well as innovation and wealth creation. The high incidence of tax non-compliance among SMEs, on the other hand, stymies the progress that SMEs are meant to bring to many nations. Thus, the study aim at assessing the effects of taxation on economic development with its moderating role of tax compliance. The descriptive research design with quantitative approach was employed. The population of the study consist is 10,000 SMEs operating in Kumasi currently with a sample size of 400 SMEs. The instrument for data collection in this study was questionnaire. The data that was collected was analysed using SPSS. The findings demonstrated that in formulating strategies to enhance voluntary compliance, it is crucial for the relevant authorities to be aware of, understand and appreciate taxation taxpayers' compliance behaviour and the need to provide tax education services. The results indicated that tax compliance enhanced the effectiveness of taxation to impact on economic development. The moderating role of tax compliance in the relationship between taxation and economic development was low but positive.

\section{Introduction}

The amount of revenue collected often determines a country's economic growth and development. Taxes continue to be one of the most important constituents in managing nationwide income in emerging and developed nations (Gangl, Hofmann, Kirchler, \& Torgler, 2014), which are plagued by widespread tax evasion (Schneider, Montenegro \& Buehn, 2010). According to Hanlon et al. (2015), as stated in the literature, taxation has an impact on government financial decisions. Taxes' importance as the main source of infrastructure development, public funding, and public service supply, all of which contribute to economic growth in both emerging and developed countries, has been made abundantly evident (Gangl et al., 2014). As a result, tax compliance is a major worry for countries all over the world (Khlif et al., 2016; Alon \& Hageman, 2013). However, even in industrialized countries, if there is a 'hard-to-tax' segment that simply evades tax payment or under-declares earnings in order to decrease their tax payments, tax compliance is not always 100 percent (McGee et al., 2008). In this sense, tax evasion might have serious effects, especially because the global cost of non-compliance by taxpayers is quite significant (Farrar et al., 2017).

In 2011, tax non-compliance was estimated to be worth more than US\$3.1 trillion on a global scale (Murphy, 2011). Many Arab countries have begun to significantly focus on taxes as a source of revenue in order to minimize their budget deficits, either as a result of the dramatic drop in oil prices or to lessen their over-reliance on international help (Alm, 2018). According to Randlane (2016), tax cheating of all kinds, including sales tax, salaries, and lowering the tax burden through illicit ways, has resulted in the loss of hundreds of millions of dollars in revenue. The failure to collect taxes has a negative influence on 
both the quantity and quality of services and public goods supplied by the government. As a result, governments must tackle tax evasion in order to ensure a more stable financial foundation (Zhang et al., 2016; Feld \& Schneider, 2010; Torgler \& Schneider, 2009). One way to do so is to support initiatives that encourage voluntary tax compliance. In this context, tax behavior studies typically look into aspects that can deter tax evasion and improve tax compliance. Furthermore, tax evasion imposes economic costs and responsibilities on governments, and it is at the heart of some of the most important issues in public economics.

The most evident is that it reduces tax collections, reducing taxes paid by complying taxpayers and governmental services provided to residents (Alm, 2012). Tax non-compliance also creates inequity between those who follow the law and those who do not, by shifting the tax burden to the first group and so creating a motivation for more non-compliance. It leads to inadequacies in business production as companies aim to stay small in order to facilitate non-compliance (Nur-Tegin, 2008) and divert resources to non-productive activities such forming financial subsidiaries to hide non-compliance (Alm, 2014). Noncompliance can also hamper economic growth by limiting a country's ability to provide suitable public goods, infrastructure, and human capital development (Johnson et al., 2000). Its presence necessitates the government spending resources to detect noncompliance, quantify its scope, and punish those who engage in it. Finally, it has an impact on the precision of macroeconomic data. In general, it is impossible to comprehend the full effects of taxation without taking into account tax evasion (Alm, 2018).

As a result, boosting tax compliance is a critical issue for governments, given that a major percentage of government spending is paid by taxes (Chung \& Trivedi, 2003). As a result, both policymakers and academic scholars have given the subject of tax non-compliance a lot of thought (Lee, 2018). Over the last 30 years, industrialized economies have increasingly shifted their focus from direct taxes to indirect taxation, such as sales tax and customs duties (Matthews, 2003). In most countries, sales tax is referred to as a value added tax (VAT) or a goods and services tax (GST). VAT is imposed by all members of the European Union (EU), whereas GST is imposed by some nations, such as Malaysia, Singapore, and Australia. In 1954, France became the first country in the world to impose a sales tax (Adams \& Webley, 2001). Sales tax is currently implemented in over 160 nations (Azmi et al., 2016) and over 120 countries. The sales tax is the most important source of government revenue, affecting approximately four billion people (Alm \& El-Ganainy, 2012).

Brazil, Argentina, Venezuela, and Uruguay, for example, collect around $70 \%, 65$ percent, $60 \%$, and $52 \%$ of their tax revenue via VAT, respectively (Smith, 2017). VAT, which accounts for 40 percent to 64 percent of total revenues in Portugal, Poland, Greece, Ireland, and Hungary, is the most important source of budget revenue among EU members (Dobrowolska, 2008). The majority of nations in the world have a sales tax system that boosts the influence of government spending efficiency on economic growth (Chan et al., 2017), implying that everyone should pay sales tax when buying most services and goods (Simionescu \& Albu, 2016). Sales tax, like other taxes, is prone to noncompliance, tax evasion, and ineffective enforcement (Giesecke \& Tran, 2012). Taxpayers can try to escape a jurisdiction's sales tax on specific 
commodities by purchasing them in neighboring areas and then consuming them in the relevant jurisdiction without paying the requisite use tax, or they can simply evade taxes on intangible services.

Significant exemptions (e.g., food, education, health, and services) are almost expected to be included in a broad-based retail sales tax, giving strong incentives for non-compliance. Firms can also provide fake invoices to conceal their tax liabilities, or they might simply fail to register (especially if their value-added is significant, as with service providers); taxpayers may even attempt to register as businesses to mask their own personal consumption as purchased inputs (Alm, 2018). Despite the fact that these challenges affect the majority of countries worldwide, they are more prevalent in developing countries than in Western and industrialized ones (Lee, 2016). This is demonstrated by the fact that non-compliance with sales taxes accounts for $15.9 \%$ of sales tax income in European countries, whereas it is substantially greater in developing countries (in Latin America, it reached an average of 31 percent ). Furthermore, African countries are unique in that the bulk of them rarely raise more than $17 \%$ of their GDP in tax revenue, compared to an average of $35 \%$ in industrialized economies (Masarirambi, 2013; World Bank, 2015).

It has been noted that the tax system in emerging countries, as well as the associated compliance requirements, has become a major impediment to small firms. In comparison to affluent countries, the problem of tax noncompliance in developing countries is quite widespread. Small and medium-sized firms (SMEs) are the backbone of economies around the world, driving economic progress and growth, as well as innovation and wealth creation. The high incidence of tax non-compliance among SMEs, on the other hand, stymies the progress that SMEs are meant to bring to many nations. Small and medium-sized businesses (SMEs) are believed to be more burdened by sales tax compliance than by other types of taxation (Hansford \& Hasseldine, 2012). Furthermore, SMEs account for a large share of each country's taxed population (Swistak, 2015). As a result, their tax payment compliance has a direct impact on the government's tax revenue collection (Maseko, 2014). Unfortunately, tax non-compliance is a common feature of SMEs all over the world (Pope \& Abdul-Jabbar, 2008).

In developing nations, SMEs are thought to be the biggest contributors to the shadow economy (Arachi \& Santoro, 2007), particularly in Jordan (See sub-section 1.1.1). They are typically owner-operated firms, as opposed to larger corporations, and thus highly responsive to personal and social influences (e.g., Swistak, 2015). Since the early 2000s, the taxation of SMEs has piqued the interest of both developing and established countries. The issue of an overwhelming number of SMEs failing to meet their tax compliance obligations demands special attention, thus it should be addressed (Swistak, 2015). Governments face a serious problem with SMEs not paying their taxes. However, the factors that influence SMEs' tax non-compliance have not been thoroughly examined in the tax literature (Abdixhiku, Krasniqi, Pugh \& Hashi, 2017). The empirical findings on the factors affecting SMEs' tax compliance are varied, implying a widespread problem with SMEs' owner-managers' compliance behavior (Battisti \& Deakins, 2017). In Ghana, various studies have been conducted on how SMEs handle tax payments. 
According to these studies, tax compliance may be improved by focusing on establishing and improving mutuality with the state (Ayee, 2007; Atubuga, 2006; Boateng, 2015). While these research enlightened us on contextual factors affecting tax compliance, they omitted the impact of religion and religiosity on tax compliance among SMEs in Ghana. Examining the influence of religion on SMEs' tax compliance behavior is critical because Islam and Christianity account for around $80 \%$ of Ghana's economy, and Ghanaians are known for their religious practices (Asamoah-Gyadu, 2005). Using primary data acquired from SMEs, this study will expand our understanding of taxpayers' complicated attitudes from a different angle, namely religion and religiosity in Ghana. As a result, the goal of this research is to see how religious values and beliefs affect SMEs' tax compliance attitudes, as evaluated by voluntary and enforced tax compliance.

Business tax compliance has received a lot of media attention in recent years (Mickiewicz et al., 2017). In particular, taxation of SMEs has piqued interest in both developing and developed countries over the last decade (Alshira'h \& Abdul-Jabbar, 2019a; Pope \& Abdul-Jabbar, 2008), with SMEs proving to play a key role in the tax system. To make matters worse, despite the fact that SMEs' owners/managers are more prone than other taxpayers to perpetrate tax fraud (Kirchler et al., 2006), tax behavior of SMEs has gotten remarkably little attention in the literature (Alshira'h \& Abdul-Jabbar, 2019b; Battisti \& Deakins, 2017). As a result, greater research on taxation in respect to SMEs is required (Swistak, 2016). The literature search found that no prior study has investigated the effects of taxation on economic development with the moderating role of tax compliance among SMEs in the Fischer's model on sales tax compliance of SMEs in Africa, generally, more especially in Ghana. Thus, the study aim at assessing the effects of taxation on economic development. Also, to assess the moderating role of tax compliance in the relationship between taxation and economic development among SMEs in Ghana.

\section{Literature Review}

Small and medium enterprises (SMEs) play a major role in the economies of most countries (Atawodi \& Ojeka, 2012). They constitute the most dynamic companies in the transitional economies and developing countries (Akimova, 2002). In other words, successful SMEs play a unique function in the economic and social development in both developing and developed countries, and they have a great role in reducing unemployment and poverty (Magableh et al., 2011). In Ghana, SMEs have the capacity to raise exports, provide foreign currency, and reduce the equilibrium of the payment deficit, as well as provide services, goods, and materials for larger companies (Alrousan \& Jones, 2016; Saymeh \& Sabha, 2014). Thus, the SMEs helps in enhancing the economy in Ghana. The definition of SMEs varies from one country to another according to several factors listed below (Berisha \& Pula, 2015; Brainyyah, 2013). Accordingly, there are some standards that should be taken into consideration including the volume of sales, number of employees, and asset value (Gibson \& Van der Vaart, 2008). Therefore, selecting a particular definition for SMEs is a hard and a complex matter (Berisha \& Pula, 2015). In Jordan, SMEs are defined according to the number of employees. In its classification of the SMEs, The Ministry of Industry and Trade (MIT) in Jordan applied the number of employee's standard. This standard is used to differentiate between large 
and SMEs business, and is one of the fundamental standards and the most used one (Saymeh \& Sabha, 2014).

The number of the employees has some benefits, namely it facilitates a comparison between sectors and countries, which can be measured to a fixed and uniform standard, and, it is not linked to price change or exchange rate changes, and the information about it can be easily collected. Therefore, the current study uses the number of the employees as the basics for defining the SMEs in Jordan. Jordanian SMEs do not keep good accounting records (Al-Smirat, 2013), lack disclosure of financial statements and required information (Al-Bakri, Matar \& Nour, 2014). Bribery is more common among SMEs than large enterprises because SMEs believe they face disproportionate compliance requirements Jordan (International Business Publications [IBP], 2016). Accordingly, the consequences of such behaviour have an effect on the tax compliance. Hence, there is a need to conduct more studies on taxation in relation to SMEs. However, the tax authority stated that most taxes derive from large businesses including around threequarters of the total tax revenues and the remaining taxes come from SMEs (ISTD, 2016), signifying low tax revenues from SMEs comparatively. Judging from the UNDP (2012) report on the shadow economy in Jordan, the low percentage of tax revenues from SMEs sector is probable due to its high contributions to the informal sector.

Examining SMEs tax commitment has attracted the interest of several studies due to several reasons listed as follows. First, SMEs are considered to have less tax commitment compared to large companies (Akinboade, 2015). Second, SMEs are important for the development and the economic growth in most countries (Maseko, 2014; Pope \& Abdul-Jabbar, 2008), and third, SMEs collect sales taxes on behalf of the state (Akinboade, 2015). Consequently, the tax compliance of SMEs influences the magnitude of tax revenue that impacts the government's capacity to achieve its social, economic and fiscal objectives (Akinboade, 2015). In Jordan, there are eight (8) economic sectors: agriculture, manufacturing, electricity, gas, and water, construction, wholesalers, trade, restaurants, and hotels, transportation, storage, and communications, services sector, financial sector, real estate, and business services (Jordan Investment Commission [JIC], 2018). As a result, the industrial sector is one of Jordan's most promising sectors, owing to the large number of industrial cities and development areas concerned with the support of medium and small industries, many of which have benefited from Jordan's free trade agreements and links with other sectors such as transportation, insurance, and trade. As a result, it is concluded that this sector plays a larger role, providing almost $40 \%$ of GDP directly or indirectly.

\section{Tax Compliance Theories}

According to Zikmund, Babin, Carr \& Griffin (2013), a theory is a formal, testable explanation of some events that includes explanations of how things interact. The previous studies have shown that numerous factors influence the tax compliance behaviour (Damayanti, 2012; Ross \& McGee, 2012). Therefore, adopting some factors alone may be unable to explain the complex nature of the tax compliance, as well as using one theory could be insufficient in explaining the phenomenon of the tax compliance (Ayuba, Saad \& Ariffin, 2016). As a result, explaining tax compliance necessitates recognizing 
the numerous elements that inspire tax behavior; these aspects may extend beyond the usual economicsof-crime approach to include psychological and sociological theories of behavior. According to Kasipillai \& Abdul-Jabbar (2006), tax compliance difficulties are linked to a variety of other disciplines, including psychology, accounting, political science, economics, and public administration. Al-Ttaffı \& Abdul-Jabbar (2015) highlighted that the economic and socio-physiological theories could reasonably clarify the complex essence of the tax compliance. In this regard, Andreoni, Erard \& Feinstein (1998) stated that integrating the economic theory with the social psychology theory is essential. In addition, Sapiei, Kasipillai \& Eze (2014) asserted that the behavioural and economic approaches play a major role in understanding and explaining the tax compliance behaviour. The economic approach is based on the idea of the economic rationality, whereas the behavioural approach follows concepts from sciences, such as sociology and psychology. Therefore, the present study considers using the socio-psychological and deterrence theories as the best ones to explain the tax compliance behaviour. Consequently, the current study is based on the deterrence approach and the socio-psychological approach associated with Fischer's model in determining the sales tax compliance among the Jordanian SMEs.

\subsubsection{Deterrence Theory}

In terms of the economic approach, historically, deterrence has been the most common tactic for enforcing tax compliance (Frey, 2003). Becker's (1968) model of economics-of-crime has created economic studies on tax non-compliance; the model is used to combat unlawful activities. Hence, the deterrence policy is founded on the simple idea that the threat of legal penalties will prevent crime. Becker's (1968) assumption implies that taxpayers have a rational behaviour; each taxpayer is supposed to maximize the expected utility of the tax non-compliance gamble, weighing the benefits from successful tax non-compliance against the tax audit and penalty. This hypothesis is obviously founded on the reality that a taxpayer pays taxes out of fear of being discovered and punished if he or she does not pay taxes (Alm, 2012). Allingham \& Sandmo (1972) were the first to use Becker's (1968) model of crime to construct the idea of tax non-compliance. The A-S model, which is also known as a deterrence theory (economic method) or an expected utility maximization model, is the oldest model for resolving tax non-compliance. This idea suggests that the tax system has the power to reduce tax non-compliance through punishment and fear. The model of the deterrence theory (Financial self-interest model of taxpayer compliance), the basic deterrence framework supposes that the threat of fines, penalties and tax audit are the main mechanism to improve tax compliance (Kuperan \& Sutinen, 1998).

Tax audit is defined as the probability that the tax authority will discover taxpayers who do not comply with the tax laws through tax audit and auditing programs, whereas tax penalty is sanction and fine imposed on taxpayers who do not comply to paying taxes. Tax non-compliance is considered an economic crime, in which fines are the most prevalent and significant form of punishment for this kind of behaviour (Isa, 2012). The aim of deterring non-compliance is usually by generating fear, increasing the size of a fine, and increasing the tax audit (Forest \& Sheffrin, 2002). The deterrence approach supposes that the "external forces" promote taxpayers towards tax compliance (Ariel, 2012). Thus the deterrence theory presents evidence about the predictable connection between the increased deterrence efficiency 
and the deterred behaviour. In a tax obligation frame, this indicates that increasing the deterrence actions will result in increasing the obligation. In contrast, the reduction in the deterrence actions should result in a decrease in the tax compliance. Consequently, deterrence is needed to prohibit taxpayers from tax cheating (Verboon \& Dijke, 2012). On the other hand, Dwenger, Kleven, Rasul \& Rincke (2014) found that deterrence has an insignificant influence on the intrinsic motivation of tax compliance, whereas it has a large influence on the extrinsic motivation for tax compliance.

Similarly, Wenzel (2004) declared that deterrence is only appropriate and influential for taxpayers who do not have tax morals, whereas it is ineffective for taxpayers who have tax morals. In addition, the deterrence threat certainly increases tax obligations, whereas it rarely ensures full obligation (Brockmann, Genschel \& Seelkopf, 2015). In this regard, Feld \& Frey (2007) revealed that the deterrence approach to tax non-compliance cannot increase tax compliance rates without used in conjunction with other methods. However, by depending only on deterrence, the punishment may at times seem problematic and even counterproductive (Leonardo, 2011). In many countries, even though the deterrence degree is too low, the level of tax compliance is high (Torgler, 2007). Thus researchers argue that non-economic factors can help solve this issue (Torgler \& Schneider, 2009). However, this method is problematic as it conflicts with empirical facts. Therefore, it is expected that a new way to enforce taxes will be found based on a psychological approach to economics (Frey, 2003). Furthermore, many additional elements that may have a significant impact on taxpayer compliance behavior, including as socio-psychological determinants and demographic traits, are not taken into account in the economic approach. To summarize, the deterrence strategy is insufficient to explain why many people willingly obey the tax regulations.

\section{Effects of taxation on economic development}

In both rich and developing countries, taxes are important components of overall domestic revenue. Countries benefit from their substantial reliance on both direct and indirect taxes to boost their economies (Torgler \& Schneider, 2009). Tax compliance is a legal requirement for everyone, whether they work for a company or are self-employed. As a result, everyone is expected to willingly comply with tax laws, yet some people do not (Kirchler, Niemirowski \& Wearing, 2006). As a result, tax evasion by businesses and individuals is a significant concern for tax authorities. In terms of the causes of tax evasion in Egypt, NurTegin (2008) attempted to identify the primary causes of tax evasion in Egyptian society. The findings showed that a lack of openness in government spending boosted tax avoidance. Tax loopholes and a lack of confidence between taxpayers and the government exacerbated income tax evasion. In Syria, taxpayers lack morals and are unwilling to pay their taxes, as well as a lack of trust between them and the government. Furthermore, the government's products and services were disproportionately large in comparison to the size of tax payments, the government did little for taxpayers, the tax rate was excessive, and the tax system was unfair. In their investigation on the causes of tax avoidance in Syria. Tax evasion amounted to roughly 200 billion Syrian Pounds, the tax system was ineffective, tax department employees were paid low wages and salaries, and an increase in the tax rate or unemployment was positively connected with tax evasion. A rise in tax rate was positively associated to 
an increase in tax evasion and governmental income, and a reduction in tax evasion was favorably related to a reduction in tax evasion.

There is a link between tax system fairness and reduced tax evasion. Martinez-Vazquez \& Rider (2005) found that tax complexity and tax injustice were both positively connected with tax evasion in another study. Mahangila (2014) claimed that the lack of security and political stability in Palestine was a major factor in the rise of income tax evasion. Abdul-Jabbar (2009) linked the phenomena of income tax evasion in the Gaza Strip to the inefficiency of the tax penalty, Palestine's political and economic instability, and the lack of collaboration between the tax administration and taxpayers. Similarly, a study by Dunn, Farrar \& Hausserman (2018) on the main reasons for the rise in income tax evasion in the Gaza Strip found that a lack of security and political stability, full Palestinian authority sovereignty over the Palestinian territories, and a lack of transparency in public spending were all positively related to tax evasion. The findings on tax evasion were also analyzed by Alm, Liu \& Zhang (2018), who stated that the tax authority had major structural and functional inadequacies, which led to the taxpayer's ignorance of the importance and aims of tax, resulting in increased tax evasion. Using questionnaires provided to 12 external auditors and 18 income tax auditors, Alm \& Torgler (2011) attempted to determine the impact of tax evasion on Jordan's sustainable growth. They discovered that evasion is on the rise in Jordan, and that it is a deliberate and premeditated behavior. It was also discovered that taxpayers paid large sums of money to tax experts to assist them in avoiding paying taxes. Al- Bakri (2010) used questionnaires issued to 173 external auditors to investigate factors affecting corporate tax avoidance. It was found that tax penalty, tax rate and company size have a significant effect on income tax evasion.

\section{H1: There is a significant effect of taxation on economic development.}

\section{Moderating role of tax compliance}

Tax is a term used to describe a mandatory payment made by people on their wealth to help pay for government expenses (Khasawneh et al., 2008). Even while wages, earnings, and other types of income are taxed, some specific products are frequently exempt from taxation, usually because to a tax authority's desire to encourage a particular behavior (Payne \& Raiborn, 2018). Tax compliance, on the other hand, is unquestionably important for a nation's successful operation. Despite the fact that tax compliance studies and research began in the early 1970s (Alm \& Torgler, 2011), Fischer et al. (1992) emphasized that there are no universal definitions of tax compliance and non-compliance. As a result, there have been a variety of interpretations and definitions of tax compliance in the literature. Roth et al. (1989) defined tax compliance as "the taxpayer files all required tax returns on time and the returns accurately show tax liabilities in conformity with the laws, regulations, and court decisions in effect at the time the return is filed." According to Jackson \& Milliron (1986), tax compliance entails reporting all income and paying taxes in accordance with laws, court rulings, and regulations. In the context of this study, sales tax compliance is defined as timely filing of tax returns, reporting, and payment of the correct amount of tax, as well as conformity with goods and services tax legislation and administration (Zainan et al., 2017). 
Tax non-compliance, as contrast to tax compliance, refers to a taxpayer's failure to meet the obligations of tax reporting (Abdul-Jabbar \& Pope, 2008). Non-compliance that is both unintentional and intentional is included in this definition. Meanwhile, Sikka (2013) defined tax evasion as any doubtful or dishonest purposefully behavior outside the legal framework to boost deductions, conceal taxable income levels, or reduce the proper tax due. Tax avoidance (or tax mitigation) is described by Payne \& Raiborn (2018) as the process of employing lawful measures to lower the amount of tax owing based on specified provisions in the tax legislation. However, no consensus has emerged in the literature on a particular definition of tax compliance that encompasses all of the numerous dimensions of tax compliance. Furthermore, tax non-compliance can take many forms, including failure to pay taxes on time, failure to file a tax return, understatement of income, and overstatement of deductions (Kasipillai \& Abdul-Jabbar, 2006). In addition to other taxes, sales tax has a number of options for noncompliance, as businesses can simply underreport sales, fail to register for sales tax, or issue inaccurate tax invoices, allowing them to understate their tax obligations (Alm et al., 2016). Successful tax collection, according to research in the field of tax compliance, entails the use of coercive force and power, persuasion, moral principles, and a sense of the tax system's fairness. However, there is no agreement on why people pay or do not pay taxes.

Deterrence theory was one of the first models used to explain tax compliance behavior (Jackson \& Milliron, 1986). The deterrence hypothesis proposes, among other things, that the danger of being caught is a more potent deterrent for criminal action than punishment, and that increasing the impression of the likelihood of getting caught serves to reduce crime (Becker, 1968). The Becker (1968) model of criminal economics inspired the concepts of deterrence theory. Becker claimed that the level of tax noncompliance is determined by determinants such as audit and fines. Allingham \& Sandmo (1972), following Becker (1968), proposed a criminal model to construct the idea of tax evasion. The deterrence theory (economic method) or the anticipated utility maximization model are both examples of the A-S model. The A-S model implies that taxpayers act rationally and that each one wants to maximize the expected utility of the tax non-compliance bet, balancing the benefits of successful tax non-compliance against the risk of being discovered by an audit and facing a penalty.

It is one of the oldest theories for resolving the tax compliance conundrum. According to this idea, a high level of both tax audits and tax fines, as well as a high tax rate, are essential factors in deterring illicit behavior by taxpayers. However, as indicated by the early model, this form was limited to the strict economic aspects of tax non-compliance, ignoring the social issues (Molero \& Pujol, 2012). The ability of the tax system to reduce the phenomenon of tax non-compliance through penalty and fear is referred to as deterrence theory. The deterrence theory is commonly used to understand tax compliance of an individual's behavior in the area of income tax, but few studies have employed it in the context of sales tax compliance, even in wealthy nations, let alone developing countries (Woodward \& Tan, 2015; Adams \& Webley, 2001). When discussing the factors of tax compliance, Casal et al. (2016) argued that it is hard to ignore the concepts of deterrent devices used by tax departments to combat tax non-compliance. The factors that influence sales tax compliance are discussed in the next section. 
H2: There is a moderating effect of tax compliance in the relationship between taxation and economic development.

\section{Methodology}

The descriptive research design with quantitative approach was employed. The current study adopted a survey design since the questionnaire is directed to a sample to investigate the effects of taxation on economic development with the moderating role of tax compliance among SMEs in Ghana hypotheses development. The study data was input in numbers and analyzed using statistical procedures to test the hypothesis.

\section{Population and Sample size}

The study population included owners of SMEs in Kumasi, Ghana. The population of the study consist is 10,000 SMEs operating in Kumasi currently. The sample size is four hundred (400) representing $4 \%$ of the population. Since the population is large, convenient sampling technique was employed to get the sample for the study.

\section{Data collection}

The instrument for data collection in this study was questionnaire. To analyse hypotheses, a questionnaire survey was administered to owners of SMEs in Kumasi. The format of the questionnaire was in four parts. Part one will consist of the demographic characteristics of participants and instructions on how the instrument should be answered. The second, third and fourth section included questions or items addressing the objectives of the study. The questionnaire provided the study's aims and guidelines, confidentiality and anonymity of participants. To minimize the risk of mistakes, supplementary guidance on how the questionnaire should completed.

\section{Measure}

Adopted items from Alshira'h \& Abdul-Jabbar (2019) was used to measure tax compliance with the help of a questionnaire.

\section{Data analysis technique}

The data that was collected was analysed by measuring the coefficients of Cronbach's alpha to determine the level of internal consistency. A 0.70 or more value for Cronbach's alpha indicates that a construct is accurate. The coefficients of Pearson correlation was then determined to see if the variables correlate to each other. The Harman test would be used by the researcher to ensure that the collected data does not contain a large amount of a bias method that is common.

\section{Results}




\section{The effects of taxation on economic development}

The $\mathrm{R}$ value in Table 1 is $.166^{\mathrm{a}}$ which means that the relationship between taxation and economic development is weak but positive. The R Square of the model summary illustration is .028 which means the significant impact of taxation account for only $2.8 \%$ of the contribution of factors that influence economic development. Hence, the model fit the study. The Std. Error of the Estimate between the variables is .67444 which is the average error for the model fit. How small the Std. Error of the Estimate is means that the model is good. The F Change for the model is 7.381 which is significant and it means that the R-squared does not equal to zero.

Table 1

Model Summary on effects of taxation on economic development

\begin{tabular}{|c|c|c|c|c|c|c|c|c|c|}
\hline \multirow[t]{2}{*}{ Model } & \multirow[t]{2}{*}{$\mathbf{R}$} & \multirow{2}{*}{$\begin{array}{l}\mathrm{R} \\
\text { Square }\end{array}$} & \multirow{2}{*}{$\begin{array}{l}\text { Adjusted } \\
\text { R Square }\end{array}$} & \multirow{2}{*}{$\begin{array}{l}\text { Std. Error } \\
\text { of the } \\
\text { Estimate }\end{array}$} & \multicolumn{5}{|c|}{ Change Statistics } \\
\hline & & & & & $\begin{array}{l}\mathrm{R} \\
\text { Square } \\
\text { Change }\end{array}$ & $\begin{array}{l}\text { F } \\
\text { Change }\end{array}$ & df1 & $\mathrm{df2}$ & $\begin{array}{l}\text { Sig. F } \\
\text { Change }\end{array}$ \\
\hline 1 & $.166^{a}$ & .028 & .024 & .67444 & .028 & 7.381 & 1 & 398 & .007 \\
\hline
\end{tabular}

The relationship between economic development and the model was statistically significant. Moreover, the p-value in Table 2 is $.007^{b}$ which is less than .01 . This evidence that the regression model fits the data better than the model with no independent variables. The degree of freedom (398 - df1) is 399 which refers to the maximum number of logically independent values and have the freedom to vary in data sample without breaking any constraints.

Table 2

ANOVA $^{\mathrm{a}}$ on effects of taxation on economic development

\begin{tabular}{|c|c|c|c|c|c|c|}
\hline \multicolumn{2}{|c|}{ Model } & \multirow{2}{*}{$\begin{array}{l}\text { Sum of Squares } \\
3.357\end{array}$} & \multirow{2}{*}{$\begin{array}{l}\text { df } \\
1\end{array}$} & \multirow{2}{*}{$\begin{array}{l}\text { Mean Square } \\
3.357\end{array}$} & \multirow{2}{*}{$\begin{array}{l}\mathbf{F} \\
7.381\end{array}$} & \multirow{2}{*}{$\begin{array}{l}\text { Sig. } \\
.007^{t}\end{array}$} \\
\hline 1 & Regression & & & & & \\
\hline & Residual & 118.265 & 398 & .455 & & \\
\hline & Total & 121.622 & 399 & & & \\
\hline \multicolumn{7}{|c|}{ a. Dependent Variable: economic development } \\
\hline \multicolumn{7}{|c|}{ b. Predictors: (Constant), taxation } \\
\hline
\end{tabular}

In Table 3, taxation showed a positive relation with economic development $(B=.166, \mathrm{t}=2.717)$. 
Table 3

Coefficients ${ }^{\mathrm{a}}$ on effects of taxation on economic development

\begin{tabular}{|c|c|c|c|c|c|c|}
\hline \multirow{2}{*}{\multicolumn{2}{|c|}{ Model }} & \multicolumn{2}{|c|}{ Unstandardized Coefficients } & \multirow{2}{*}{$\begin{array}{l}\text { Standardized Coefficients } \\
\text { Beta }\end{array}$} & \multirow[t]{2}{*}{$t$} & \multirow[t]{2}{*}{ Sig. } \\
\hline & & B & Std. Error & & & \\
\hline \multirow[t]{2}{*}{1} & (Constant) & 1.610 & .124 & & 12.971 & .000 \\
\hline & taxation & .107 & .039 & .166 & 2.717 & .007 \\
\hline
\end{tabular}

The moderating role of tax compliance in the relationship between taxation and economic development

Process macro is purposely used for variables that are performing mediating and moderating role in a framework (Hayes 2013). Since the current study had tax compliance as a moderating variable, Andrews F. Hayes PROCESS v4.0 was adopted (Hayes \& Preacher 2014). The sample size was 400. Results shown in Table 4 disclosed that taxation positively and significantly related to economic development $(B=$ $.7430, \mathrm{t}=6.7464, p=.0000)$. This specified that path of taxation to economic development was significant. Additionally, tax compliance positively and significantly related to economic development $(B=$ $.6314, \mathrm{t}=6.3632, p=.0000$ ). This specified that path of tax compliance to economic development was significant. Lastly, taxation and tax compliance negatively but significantly related to economic development $(B=-.2322, \mathrm{t}=-6.6581, p=.0000)$ as shown in Table 4 . This specified that path of the moderation model was significant. The results indicated that tax compliance enhanced the effectiveness of taxation to impact on economic development.

Table 4

Process macro with tax compliance as a moderator

\begin{tabular}{|c|c|c|c|c|c|c|}
\hline Mode 1 & Coeff & Se & $\mathbf{t}$ & $\mathbf{p}$ & LLCl & ULCI \\
\hline Constant & .0470 & .2593 & .1812 & .8563 & -.4637 & .5577 \\
\hline taxation & .7430 & .1101 & 6.7464 & .0000 & .5261 & .9599 \\
\hline tax compliance & .6314 & .0992 & 6.3632 & .0000 & .4360 & .8268 \\
\hline Int_1 & -.2322 & .0349 & -6.6581 & .0000 & -.3009 & -.1636 \\
\hline \multicolumn{7}{|c|}{ Effect tax compliance } \\
\hline 1.2500 & .2785 & .0552 & 5.0490 & .0000 & -.1699 & .3872 \\
\hline 2.0000 & .0463 & .0464 & .9981 & .3192 & -.0450 & .1376 \\
\hline 4.0000 & -.1860 & .0607 & -3.0614 & .0024 & -.3056 & -.0663 \\
\hline
\end{tabular}


In this model, values were shown with the total value for $p, F$, and R Square. Moderating variable represented tax compliance was entered to predict economic development. The $\mathrm{R}$ value in Table 5 is .4163 which means that the moderating role of tax compliance in the relationship between taxation and economic development is low but positive. The R Square of the model summary illustration is .1733 which means the significant moderating impact of tax compliance in the relationship between taxation and economic development account for only $17.33 \%$ of the contribution of factors that influence the impact of taxation on economic development. The MSE (Error) of the Estimate between the variables is .3897 which is the average error for the model fit. How small the MSE of the Estimate is means that the model is good. The F Change for the model is 18.0237 which is significant and it means that the Rsquared does not equal to zero. The p-value is $.000^{\mathrm{b}}$ which is less than .01 . This evidence that the Process Macro model fits the data better than the model with no independent variables. The degree of freedom (398 - df1) is 399 which refers to the maximum number of logically independent values and have the freedom to vary in data sample without breaking any constraints.

Table 5

Model Summary

\begin{tabular}{|lllllll|}
\hline $\mathbf{R}$ & R-sq & MSE & F & df1 & df2 & p \\
\hline \multirow{2}{*}{4163} & .1733 & .3897 & 18.0237 & 1 & 398 & .000 \\
\hline
\end{tabular}

\section{Conclusion And Future Studies}

The primary objective of this research was to assess the effects of taxation on economic development. Also, to assess the moderating role of tax compliance in the relationship between taxation and economic development among SMEs in Ghana. This research was a survey employing descriptive research design, quantitative approach, and questionnaire. Findings revealed that taxation and tax compliance negatively but significantly related to economic development. This specified that path of the moderation model was significant. The results indicated that tax compliance enhanced the effectiveness of taxation to impact on economic development. The moderating role of tax compliance in the relationship between taxation and economic development was low but positive. The findings of this research provide evidence that taxation and tax compliance promote economic development. The findings demonstrated that in formulating strategies to enhance voluntary compliance, it is crucial for the relevant authorities to be aware of, understand and appreciate taxation taxpayers' compliance behaviour and the need to provide tax education services. There is a need for trust to be built between the citizens and the state. To facilitate this, transparency and accountability in the tax system must be enforced and publicised. A further study into how tax knowledge and changes to tax regulations and laws affect compliance decisions could be beneficial.

\section{Declarations}

Competing interest: The author declares no competing interests. 


\section{References}

Abdixhiku, L., Krasniqi, B., Pugh, G., \& Hashi, I. (2017). Firm-level determinants of tax evasion in transition economies. Economic Systems, 41(3), 354-366.

Abdul-Jabbar, H. \& Pope, J. (2008). Exploring the relationship between tax compliance costs and compliance issues in Malaysia. Journal of Applied Law and Policy, 1(1), pp. 1-20.

Abdul-Jabbar, H. (2009). Income tax non-compliance of small and medium enterprises in Malaysia: Determinants and tax compliance costs. (Unpublished doctoral thesis, Curtin University of Technology).

Adams, C. \& Webley, P. (2001). Small business owners' attitudes on VAT compliance in the UK. Journal of Economic Psychology, 22(2), pp. 195-216.

Akimova, I. (2002). Performance of small and medium sized manufacturing firms in Ukraine: Does the quality of governance matter? business environment for SMEs in Ukrain. In S. Cramon-Taubadel \& I. Akimova (Eds.), In Fostering Sustainable Growth in Ukraine (pp. 160-172). Ukraine.

Akinboade, O. A. (2015). Correlates of tax compliance of small and medium size businesses in cameroon. Managing Global Transitions, 13(4), 389-413.

AL-Bakri, A. A. (2010). The adoption of business-to-business systems by small and medium enterprises in Amman and the perceptions of its influence on performance and efficiency. (Unpublished doctoral thesis, University of Southern Queensland).

Allingham, M. \& Sandmo, A. (1972). Income tax evasion: a theoretical analysis. Journal of Public Economics, 1(3/4), pp. 323-338.

Alm, J. \& McClellan, C. (2012). Tax morale and tax compliance from the firm's perspective. Kyklos, 65(1), pp. 1-17.

Alm, J. (2012). Measuring, explaining, and controlling tax evasion: Lessons from theory, experiments, and field studies. International Tax and Public Finance, 19, 54-77.

Alm, J. (2014). Tax evasion, labor market effects, and income distribution. IZA World of Labor, 91, pp. 110.

Alm, J. (2018). What are the costs of a new tax administration? The case of a personal income tax in Kuwait. Working Paper No. 1804. Department of Economics, Tulane University.

Alm, J., \& Torgler, B. (2006). Culture differences and tax morale in the United States and in Europe. Journal of Economic Psychology, 27(2), 224-246.

Alm, J., \& Torgler, B. (2011). Do ethics matter? tax compliance and morality. Journal of Business Ethics, 101(4), 635-651. 
Alm, J., Liu, Y. \& Zhang, K. (2018). Financial constraints and firm tax evasion. International Tax and Public Finance, 26(1), pp. 1-32, https://doi.org/10.1007/s10797-018-9502-7.

Alm, J., Martinez-Vazquez, J. \& McClellan, C. (2016). Corruption and firm tax evasion. Journal of Economic Behavior and Organization, 124, pp. 146-163.

Alon, A. \& Hageman, A.M. (2013). The impact of corruption on firm tax compliance in transition economies: Whom do you trust? Journal of Business Ethics, 116(3), pp. 479-494.

Alrousan, M. K., \& Jones, E. (2016). A conceptual model of factors affecting e-commerce adoption by SME owner / managers in Jordan . International Journal of Business Information Systems, 21(3), 269308.

Alshira'h, A.F. \& Abdul-Jabbar, H. (2019a). The effect of tax fairness on sales tax compliance among Jordanian manufacturing SMEs. Academy of Accounting and Financial Studies Journal, 23(2), pp. 1-12.

Alshira'h, A.F. \& Abdul-Jabbar, H. (2019b). A conceptual model of sales tax compliance among Jordanian SMEs and its implications for future research. International Journal of Economics and Finance, 11(5), pp. $1-14$.

Al-Smirat, B. Y. (2013). The use of accounting information by small and medium enterprises in South District of Jordan. Research Journal of Finance and Accounting, 4(6), 169-175.

Al-Ttaffi, L. H. A., \& Abdul-Jabbar, H. (2015). Does muslim view on tax influence compliance behaviour? Paper Presented at the International Conference on Accounting Studies (ICAS) 2015 17-20 August 2015, Johor Bahru, Johor, Malaysia.

Andreoni, J., Erard, B., \& Feinstein, J. (1998). Tax compliance. Journal of Economic Literature, 36(2), 818860 .

Arachi, G., \& Santoro, A. (2007). Tax enforcement for SMEs: lessons from the Italian experience? eJournal of Tax Research, 5(2), 225-243.

Ariel, B. (2012). Deterrence and moral persuasion effects on corporate tax compliance: findings from a randomized controlled trial. Criminology, 50(1), 27-69.

Asamoah-Gyadu, J.K. (2005). African Charismatics, Brill. Leiden.

Atawodi, O. W., \& Ojeka, S. A. (2012). Relationship between tax policy, growth of SMEs and the Nigerian economy. International Journal of Business and Management, 7(13), 125-135.

Atubuga, R. (2006). The tax culture of Ghanaian: a research report prepared for the Revenue Mobilisation Support (RMS). Legal Resource Centre; GTZ. Accra. 
Ayee, J.R. (2007). Building tax compliance through reciprocity with government. Enterprise Formalization in Africa, Foreign Investment Advisory Service of the World Bank Group, Accra, pp. 6-7.

Ayuba, A., Saad, N., \& Ariffın, Z. Z. (2016). Does perceived corruption moderate the relationship between economic factors and tax compliance? a proposed framework for Nigerian small and medium enterprises. Mediterranean Journal of Social Sciences, 7(1), 402-409.

Azmi, A., Sapiei, N.S., Mustapha, M.Z. \& Abdullah, M. (2016). SMEs' tax compliance costs and IT adoption: the case of a value-added tax. International Journal of Accounting Information Systems, 23(12), pp. 1-13.

Battisti, M., \& Deakins, D. (2017). Microfoundations of small business tax behaviour: A capability perspective. British Journal of Management, 1-17. Available at https://doi.org/10.1111/14678551.12244.

Becker, G. S. (1968). Crime and punishment: An economic approach. The Journal of Political Economy, 76(2), 169-217.

Berisha, G., \& Pula, J. S. (2015). Defining small and medium enterprises: A critical review. Academic Journal of Business, Administration, Law and Social Sciences, 1(1), 17-28.

Boateng, A.A. (2015). An examination of challenges and prospects of microfinance institutions in Ghana. Journal of Economics and Sustainable Development, 6(4), pp. 52-60.

Brainyyah, M. Q. (2013). The effect of tax fairness, tax knowledge, and tax complexity on tax compliance: The case of SME entrepreneurs' taxpayers in Malang. Jurnal IImiah Mahasiswa FEB, 1(2), 81-87.

Brockmann, H., Genschel, P., \& Seelkopf, L. (2015). Happy taxation: increasing tax compliance through positive rewards? Journal of Public Policy, 15(10), 1-26.

Casal, S., Kogler, C., Mittone, L. \& Kirchler, E. (2016). Tax compliance depends on voice of taxpayers. Journal of Economic Psychology, 56(10), pp. 141-150.

Chan, S.G., Ramly, Z. \& Karim, M.Z.A. (2017). Government spending efficiency on economic growth: Roles of value-added tax. Global Economic Review, 46(2), pp. 162-188.

Chung, J. \& Trivedi, V.U. (2003). The effect of friendly persuasion and gender on tax compliance behaviour. Journal of Business Ethics, 47(2), pp. 133-145.

Damayanti, T. W. (2012). Changes on indonesia tax culture, is there a way? studies through theory of planned behavior. Researchers World, 3(4), 8-15.

Dobrowolska, B. (2008). Value Added Tax in European Union Countries-Comparative Analysis, Acta Universitatis Lodziensis. Folia Oeconomica. 
Dunn, P., Farrar, J. \& Hausserman, C. (2018). The influence of guilt cognitions on taxpayers' voluntary disclosures. Journal of Business Ethics, 148(3), pp. 689-701.

Dwenger, N., Kleven, H., Rasul, I., \& Rincke, J. (2014). Extrinsic and intrinsic motivations for tax compliance: Evidence from a field experiment in Germany (Working Paper No. C15). Verein für Socialpolitik / German Economic Association.

Farrar, J., Kaplan, S.E. \& Thorne, L. (2017). The effect of interactional fairness and detection on taxpayers' compliance intentions. Journal of Business Ethics, 154(1), pp. 1-14. https://doi.org/10.1007/s10551-0173458-x.

Feld, L. P., \& Frey, B. (2007). Tax compliance as the result of a psychological tax contract: The role of incentives and responsive regulation. Law and Policy, 29(1), 102-120.

Fischer, C.M., Wartick, M. \& Mark, M. (1992). Detection probability and taxpayer compliance: a review of the literature. Journal of Accounting Literature, 11, pp. 1-25.

Forest, A., \& Sheffrin, S. M. (2002). Complexity and compliance: An empirical investigation. National Tax Journal, 55(1), 75-88.

Frey, B. (2003). Deterrence and tax morale in the European Union. European Review, 11(3), 385-406.

Gangl, K., Torgler, B., Kirchler, E., \& Hofmann, E. (2014). Effects of supervision on tax compliance: Evidence from a field experiment in Austria. Economics Letters, 123(3), 378-382

Gibson, T., \& Van der Vaart, H. J. (2008). Defining SMEs: A less imperfect way of defining small and medium enterprises in developing countries (Working Paper). Brookings Global Echonomy and Development

Giesecke, J. \& Tran, N.H. (2012). A general framework for measuring VAT compliance rates a general framework for measuring VAT compliance rates. Applied Economics, 44(15), pp. 1867-1889.

Hanlon, M., Maydew, E.L. \& Thornock, J.R. (2015). Taking the long way home: US tax evasion and offshore investments in US equity and debt markets. The Journal of Finance, 70(1), pp. 257-287.

Hansford, A., \& Hasseldine, J. (2012). Tax compliance costs for small and medium sized enterprises: The case of the UK. eJournal of Tax Research, 10(2), 288-303.

Hayes, AF 2013, Introduction to Mediation, Moderation, and Conditional Process Analysis: A RegressionBased Approach, Guilford Publications.

Hayes, AF \& Preacher, KJ 2014, 'Statistical mediation analysis with a multicategorical independent variable', British Journal of Mathematical and Statistical Psychology, vol. 67, no. 3, pp. 451-70. 
Income and Sales Tax Department (2016). Income tax law. Retrieved from http://www.istd.gov.jo/NR/rdonlyres/3C4FF713-AA3F-4FDC-8B98-754EE6E8F2D1/2808/. Pdf

International Business Publications (2016). Jordan investment and business guide volume 1 strategic and practical information. World Business and Investment Library, washingto DC, USA-Jordan. Chamber of industry

Isa, K. (2012). Corporate tax payers compliance variables under the self-assessment system in Malaysia: A mixed methods approach. (Unpublished doctoral thesis, Curtin University).

Jackson, B.R. \& Milliron, V.C. (1986). Tax compliance research: fifindings, problems, and prospects. Journal of Accounting Literature, 5(1), pp. 125-165.

Johnson, S., Kaufmann, D., McMillan, J. \& Woodruff, C. (2000). Why do firms hide? Bribes and unofficial activity after communism. Journal of Public Economics, 76(3), pp. 495-520.

Jordan Investment Commission. (2018). Jordan fact sheet. Retrieved from hthttps://jic.gov.jo/portal/en/why-jordan/jordan-fact-sheet

Kasipillai, J. \& Abdul-Jabbar, H. (2006). Gender and ethnicity differences in tax compliance. Asian Academy of Management Journal, 11(2), pp. 73-88.

Khasawneh, A., Obeidat, I. \& Al-Momani, A. (2008). Income tax fairness and the taxpayers' compliance in Jordan. Journal of Economic and Administrative Sciences, 24(1), pp. 15-39.

Khlif, H., Guidara, A. \& Hussainey, K. (2016). Sustainability level, corruption and tax evasion: a crosscountry analysis. Journal of Financial Crime, 23(2), pp. 328-348.

Kirchler, E., Niemirowski, A. \& Wearing, A. (2006). Shared subjective views, intent to cooperate and tax compliance: Similarities between Australian taxpayers and tax officers. Journal of Economic Psychology, 27(4), pp. 502-517.

Kuperan, K., \& Sutinen, J. G. (1998). Blue water crime: deterrence, legitimacy, and compliance in fisheries. Law \& Society Review, 32(2), 309-338.

Lee, H.C. (2016). An electronic tax invoicing improve tax compliance? A case study of the Republic of Korea's electronic tax invoicing for value-added tax. Working Paper No.7592. World Bank Group, available at: http://documents.worldbank.org/curated/en/7128814679947_10005/Canelectronic-tax-invoicingimprove-tax-compliance-a-case-study-of-the-Republic-of-Koreas-electronictax-invoicing-for-value-addedtax

Lee, K. (2018). Optimism, pessimism, audit uncertainty, and tax compliance. The BE Journal of Theoretical Economics, 18(1), pp. 1-12. 
Leonardo, G. (2011). Politics and tax morale. the role of trust, values, and beliefs, in shaping individual attitudes towards tax compliance. (Unpublished doctoral thesis, Georgia State University).

Magableh, I. K., Kharabsheh, R., \& Al-Zubi, K. A. (2011). Determinants and impact of training: the case of SMEs in Jordan. International Journal of Economics and Finance, 3(5), 104-116.

Mahangila, D. N. (2014). SME's Corporate income tax compliance in Tanzania. (Unpublished doctoral thesis, University of Southampton).

Martinez-Vazquez, J. \& Rider, M. (2005). Multiple modes of tax evasion: theory and evidence. National Tax Journal, 58(1), pp. 51-76.

Masarirambi, C. (2013). An investigation into factors associated with tax evasion in the Zimbabwe informal sector: a survey of mbare magaba informal traders", Unpublished Ph. D Thesis. Zimbabwe Open University. Harare.

Maseko, N. (2014). The impact of personal tax knowledge and compliance costs on tax compliance behaviour of SMEs in Zimbabwe. Elite Research Journal of Accounting and Business Management, 2(3), 26-37.

Matthews, K. (2003). VAT evasion and VAT avoidance: is there a European laffer curve for VAT? International Review of Applied Economics, 17(1), pp. 37-41.

McGee, R.W., Ho, S.S. \& Li, A.Y. (2008). A comparative study on perceived ethics of tax evasion: Hong Kong vs the United States. Journal of Business Ethics, 77(2), pp. 147-158.

Mickiewicz, T., Rebmann, A. \& Sauka, A. (2017). To pay or not to pay? Business owners' tax morale: testing a neo-institutional framework in a transition environment. Journal of Business Ethics, 157(1), pp. 1-19, https://doi.org/10.1007/s10551-017-3623.

Molero, J.C. \& Pujol, F. (2012). Walking inside the potential tax evader's mind: tax morale does matter. Journal of Business Ethics, 105(2), pp. 151-162.

Murphy, R. (2011). The cost of tax abuse: a briefing paper on the cost of tax evasion worldwide. Chesman, UK: Tax justice network publication. Available at: www.Taxjustice.net/wpcontent/uploads/2014/04/Cost-of-Tax-Abuse-TJN-2011.pdf

Nur-Tegin, K.D. (2008). Determinants of business tax compliance. The BE Journal of Economic Analysis and Policy, 8(1), pp. 1-28.

Payne, D.M. \& Raiborn, C.A. (2018). Aggressive tax avoidance: a conundrum for stakeholders, governments, and morality. Journal of Business Ethics, 147(3), pp. 469-487. 
Pope, J., \& Abdul-Jabbar, H. (2008). Small and medium-sized enterprises and tax compliance burden in Malaysia: Issues and challenges for tax administration. Small Enterprise Research, 16(1), 47-60.

Randlane, K. (2016). Tax compliance as a system: mapping the field. International Journal of Public Administration, 39(7), pp. 515-525.

Ross, A. M., \& McGee, R. W. (2012). Education level and ethical attitude toward tax evasion: A six-country study. Journal of Legal, Ethical and Regulatory Issues, 15(2), 93-138.

Roth, J.A., Scholz, J.T. \& Witte, A.D. (1989), Taxpayer Compliance: An Agenda for Research, University of PA Press, Philadelphia.

Sapiei, N. S., Kasipillai, J., \& Eze, U. C. (2014). Determinants of tax compliance behaviour of corporate taxpayers in Malaysia. eJournal of Tax Research, 12(2), 383-410.

Saymeh, A. A. F., \& Sabha, S. A. (2014). Assessment of Small Enterprise Financing, case of Jordan. Global Journal of Management and Business Research, 14(2), 6-18.

Schneider, F., Buehn, A., \& Montenegro, C. E. (2010). New estimates for the shadow economies all over the world. International Economic Journal 24, 443-461.

Sikka, P. (2013). Smoke and mirrors: Corporate social responsibility and tax avoidance-a reply to hasseldine and morris. Accounting Forum, 37(1), pp. 15-28.

Simionescu, M. \& Albu, L.L. (2016). The impact of standard value added tax on economic growth in CEE-5 countries: econometric analysis and simulations. Technological and Economic Development of Economy, 22(6), pp. 850-866.

Smith, R. (2017). Strategically Managing Indirect Taxes in Latin America, OECD Publishing

Swistak, A. (2015). Tax penalties in SME tax compliance. Flinancial Theory and Practice, 40(1), 129-147.

Swistak, A. (2016). Tax penalties in SME tax compliance. Financial Theory and Practice, 40(1), pp. 129147.

Torgler, B. \& Schneider, F. (2009). The impact of tax morale and institutional quality on the shadow Economy. Journal of Economic Psychology, 30(2), pp. 228-245.

Torgler, B. (2007). Tax compliance and tax morale: A theoretical and empirical analysis, Edward Elgar Publishing. UK, 1-317.

United Nations Development Programme (2012). The panoramic study of the informal economy in Jordan. Ministry of planning. Retrieved from http://inform.gov.jo/en-us/By-Date/ReportDetails/Articleld/37/mid/420/ArticleCategory/205/The-Panoramic-Study-of-the-Informal-Economy-inJordan 
Verboon, P., \& Dijke, M. Van. (2012). The effect of perceived deterrence on compliance authorities: The moderating influence of procedural justice. International Journal of Criminology and Sociology, 1, 151161.

Wenzel, M. (2004). An analysis of norm processes in tax compliance. Journal of Economic Psychology, 25(2), 213-228.

Woodward, L. \& Tan, L.M. (2015). Small business owners' attitudes toward GST compliance: a preliminary study. Australian Tax Forum, 3(2), pp. 517-550.

World Bank (2015). Tax revenue (\% of GDP)", available at: http://data.worldbank.org/indicator/gc.tax.totl.gd.zs (accessed 10 March 2017).

Zainan, N., Noor, R., Omar, N., Abd Aziz, R. \& Sanusi, S. (2017). Retailers' behavioural factors towards goods and services tax (GST) compliance: Sociological and psychological approach study. Management and Accounting Review, 16(1), pp. 167-188.

Zikmund, W. G., Babin, B. J., Carr, J. C., \& Griffin, M. (2013). Business research methods. (ninth edition). Cengage Learning, Canada. 